$$
\begin{aligned}
& \text { (4.0, s. } \\
& 6 x^{2}=0 \\
& \text { Y Y }
\end{aligned}
$$

TERRITORY OF AIASKA

$P E-096-03$

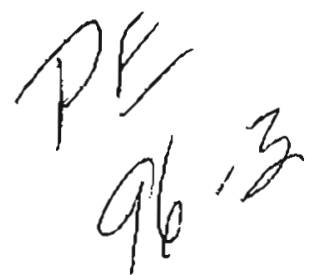

DEPARTMENT OF MTNES

\title{
EXAMINATION OF THE THREEMAN COPPER PROPERTY, PRINCE WILLIAM SOUND, ALASKA
}

\author{
by \\ JAMES A. WTUUIAYSS \\ Associate Mining Engineer
}

April 1953 
TABLE OF CONTENTS

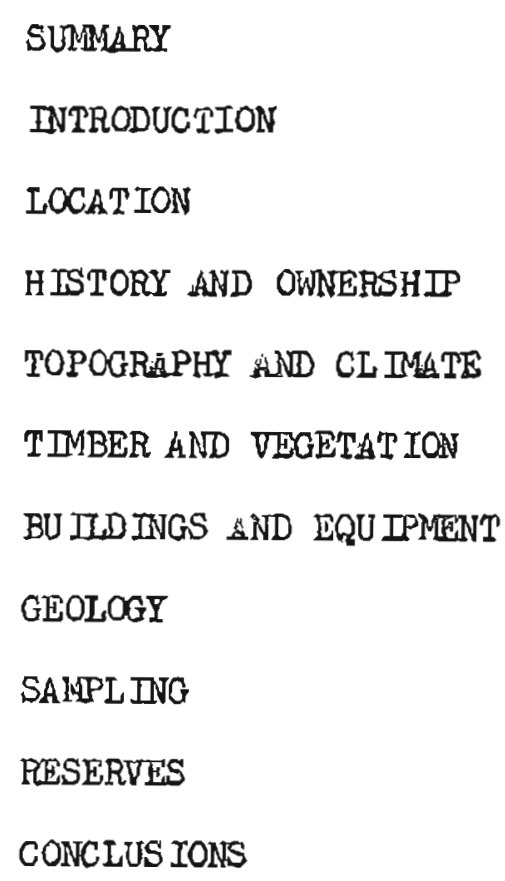

Page

1

1

2

3

4

5

5

5

7

9

II. 


\section{DLUUSTRATIONS}

Figure 1. View of Threenan property from the bay.

Figure 2. Another view of the property.

Figure 3. South portel of 5 Level (caved).

Figure 4. North portal of 5 Level (caved).

Figure 5. Portal of 3 Level.

Figure 6. Portal of north 2 Level.

Figure 7. Portal of south 2 Level.

Figure 8. Portal of 2 Level.

Figure 9. Portal of 0 Level, taken from above and to one side.

\section{PIATES}

Plate 1. Dickey Group of patented clains。

Plate 2. Vicinity map showing location.

Plate 3. Map of accessible workings. 


\section{EXAMINATION OF TKE THREEMIAN COPPER PROPERTY, PRTNCE WILLTAM SOUND, ALASKA}

\section{SUMHARY}

The Threeman Copper Mine was examined by the writer in June of 1952 as a Perritorial Department of Mines service for an eastern firm who requested ito The location is at Landlocked Bay, Pxince William Sound, between Valdez and Cordova. The exanination consisted of geological investigation, channel sampling, and mapping. Generally, the geology consists of a well-mineralized shear zone witbin which the workings are located, and from which only narrow ore shoots have been mined. The copper minerals are chalcopyrite and chalmersite. Much of the workings were inaccessible, and the extent of the examination allows only the following reserves to be assumed: proven ore, none; probable ore, 1920 tons at $2.39 \%$; and possible ore, 100,000 tons at ebout $2 \%$ with further possibilities definitely in sight.

The property shows good promise of having the necessary values for a lowgrade mllling operation. Further sampling and study should be done before any heavy investments are made toward putting the property into production.

\section{INTRODUCTION}

As part of its functions to promote and assiat the mining Industry in Alaska, the Territorial Department of Kines maintains 
a staff of mining engineers who are available for consultation and examiation of mining properties. The Threeman copper property was examined by the writer at the request of an eastern firm whtch was at that time interested in negotiating with the Threeman lining Compeny for the property. Consent was received from the owners prior to the examinetion.

The examination was made during June 21 to $26,1952$. About 1200 feet of underground workings mere examined, mapped, and sampled wherever it was safe and relatively convenient. Mepping was by tape and Brunton, and a total of twenty-two channel samples were cut. The two lower levels, probably the largest, and much of the 3 Level were inaccessible because of caved portals. The surrounding arae was inrestigated to a Iimited extent.

\section{LOCATION}

The workings of the Threeman Mine are witbin the Keystone Claim, which is one of the Dickey Group of patented claims. (See Plate 1). The geographical situation is on the north slde of the head of Landlocked Bay, a small arm of Frince William Sound which lies about 25 airline miles soutbwest of Valdez and 35 alrline miles northwest of Cordova. Plate 2 shows the location of the property on Landlocked Bay. The geographical coordinates are $146033^{\prime}$ iv Long and $60051^{\prime} \mathrm{N}$ Lat.

The property is at tidewater, and deep water transportation could serve the property if a dock were to be built off the point that lies between the workings and USIM No. 12, as shown on the two 


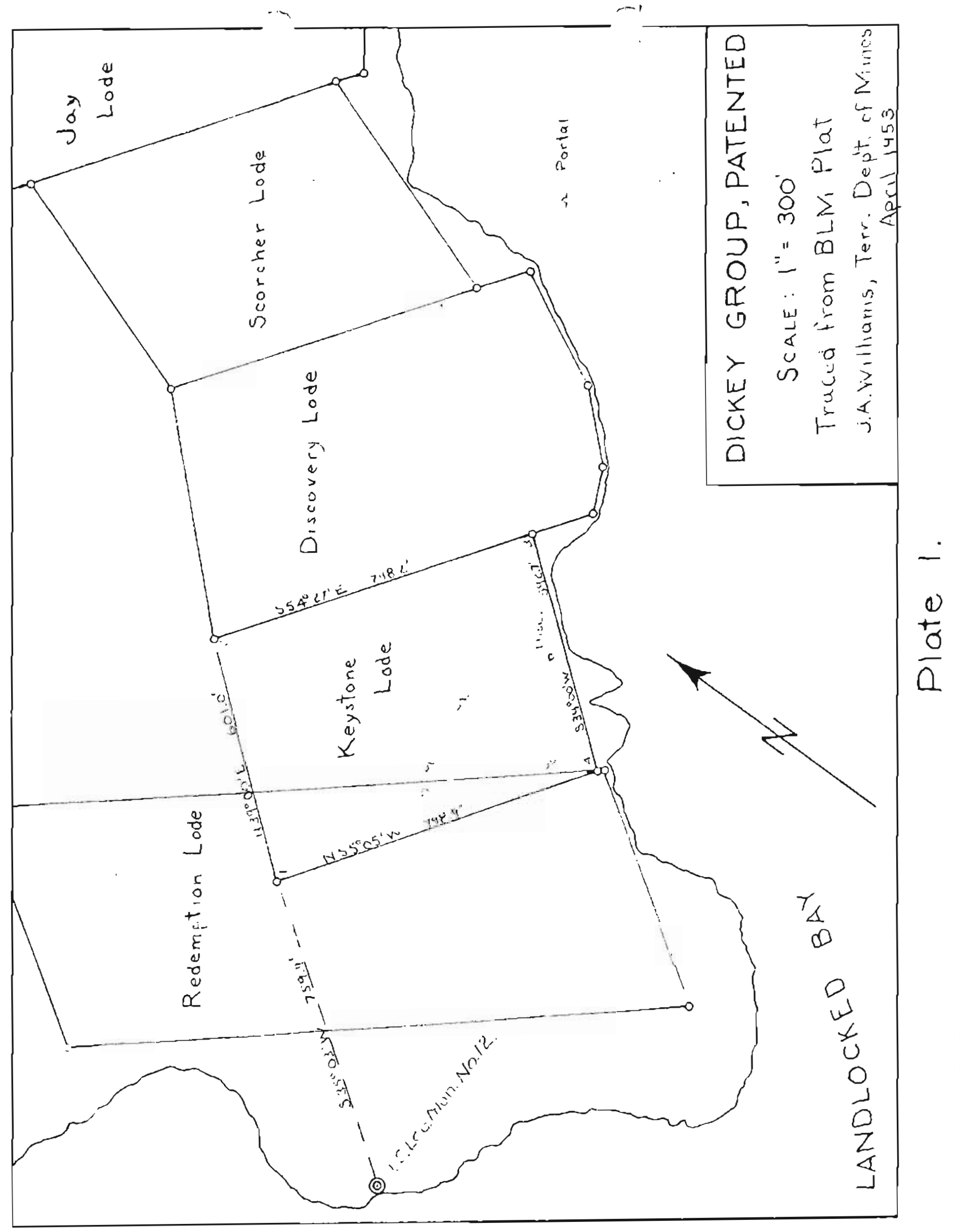




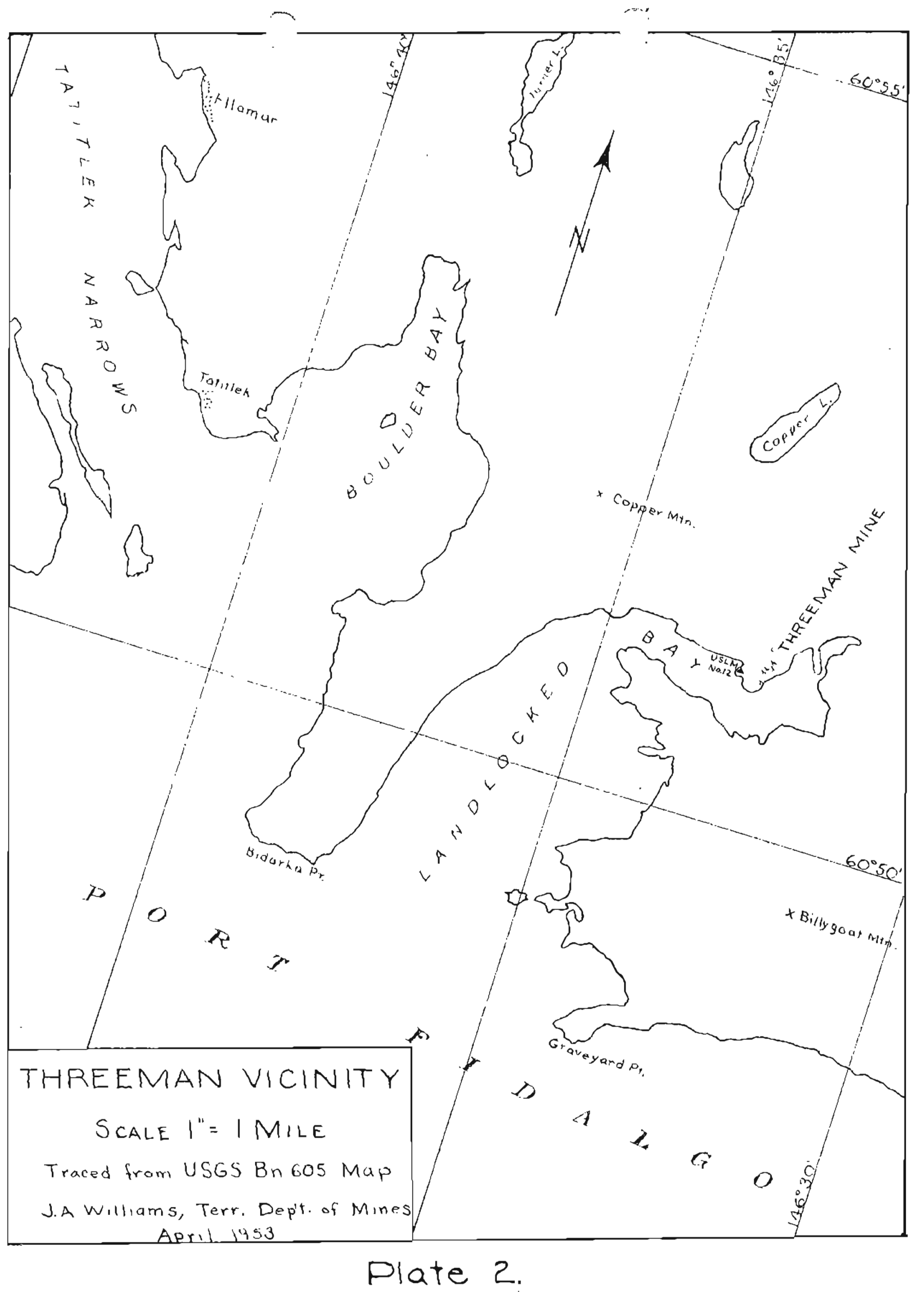


plates. The harbor should provide good protection from rough water.

HISTORY AND OWNERSHIP

Copper indications were first noted in Landlocked Bay in 1897 by a fisheman, and a claim was staked at that time. Otber copper deposits were subsequentiy found in Prince William Sound, bot the interest was temporarliy shifted northward by the stampede to the Klondike. Ore was first shipped from mines on Latouche Island in 1899 and 1900, and the interest in Prince William Sound copper was again aroused and increased until the fall of 1907 when a depression caused many plans to be abandoned.

The Threemen claims were staked in 1903, small shipments wore made in 1904 and 1906, and regular shipments were made in 1912 and 1915. The ore wes band-sorted to about $10 \%$ and shipped. Total production was about 1,000,000 1bs. of copper. Most of the development work was done between 1906 and 1912. The property has been idle since $1915^{\circ}$

As a result of visits to the property in 1912 and 1913, Bo Lo Johnson, U.S.G.S., wrote a report on it that is contained in U.S.G.S. Bulletin 605, The Ellamar District, Alaska.

The Threeman Mining Company was incorporated in 1902 in New York State, and was composed of Duncan Edwards, Henry C. Bryan, and William A. Dickey. These men have since died, and Mrs. Duncan Edwards has assumed the prestdency and kept the company in existence. Charles S. Steckmest, 8617 78th Street, Woodhaven 21, 
N. I. is the secretary and Treasurer of the compary. The company clatms ownership of a total of 13 patented and 21 unpatented claims. The location is within the Valdez Recording Pracinot, so the records on the unpatented claims will be found in the U.S. Conmisstoner'g office at Valdez, Hlaska. Plats of the patented claine are on file at the BIM office in Junean, but the records there do not show conclusively that the patents applied for were actually received. It is falrly safe to assume they were, however.

TOPOGRAPAY AND CLIMATE

The coast Iine, as can be seen on Plate 2, is very irregular. In most places, the land rises steeply from the shores. On Keyatone Clain, there was barely room along the water's edge to build the small carp buildings. This can be seen in Figures $I$ and 2. The billside is so steep that it was difficult to find dump space where the lower portals would not be covered, and in the erosion that has followed the rofre's closing, the dump material has covered or caved in 2 or 3 of the lower portals. Located less than two miles from the property, the top of Copper Hountain is 3,860 feet in elevation.

Prince Willtam Sound climate is wet. Exact figures are not known, but average annual precipitation at Landlocked Bay is probably in the range of 100 to 140 inches, including snowfall. The mean annual temperature is probably between $35^{\circ}$ and $40^{\circ}$, with average maximum and minimum sbout $70^{\circ}$ and $-5^{\circ}$, respectively. 


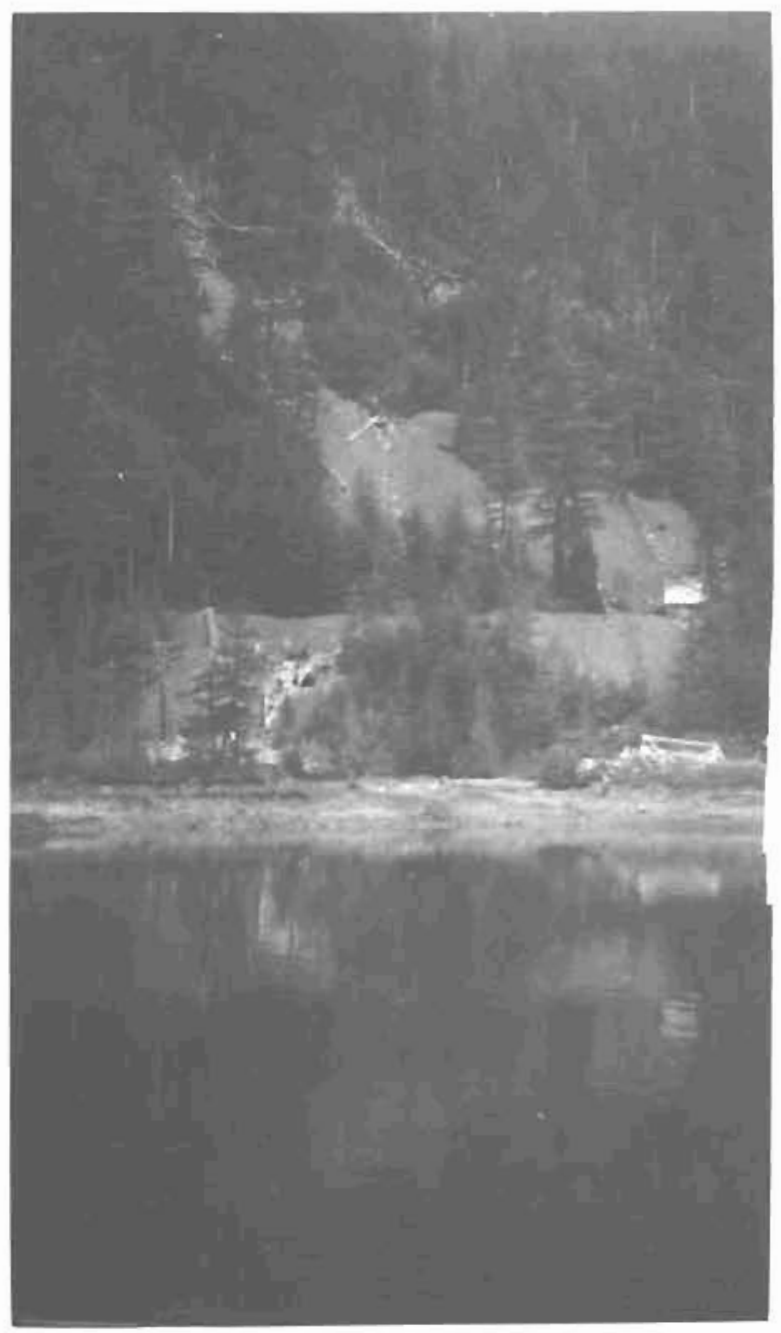

Figure 1. View of Threeman property from the bay. 


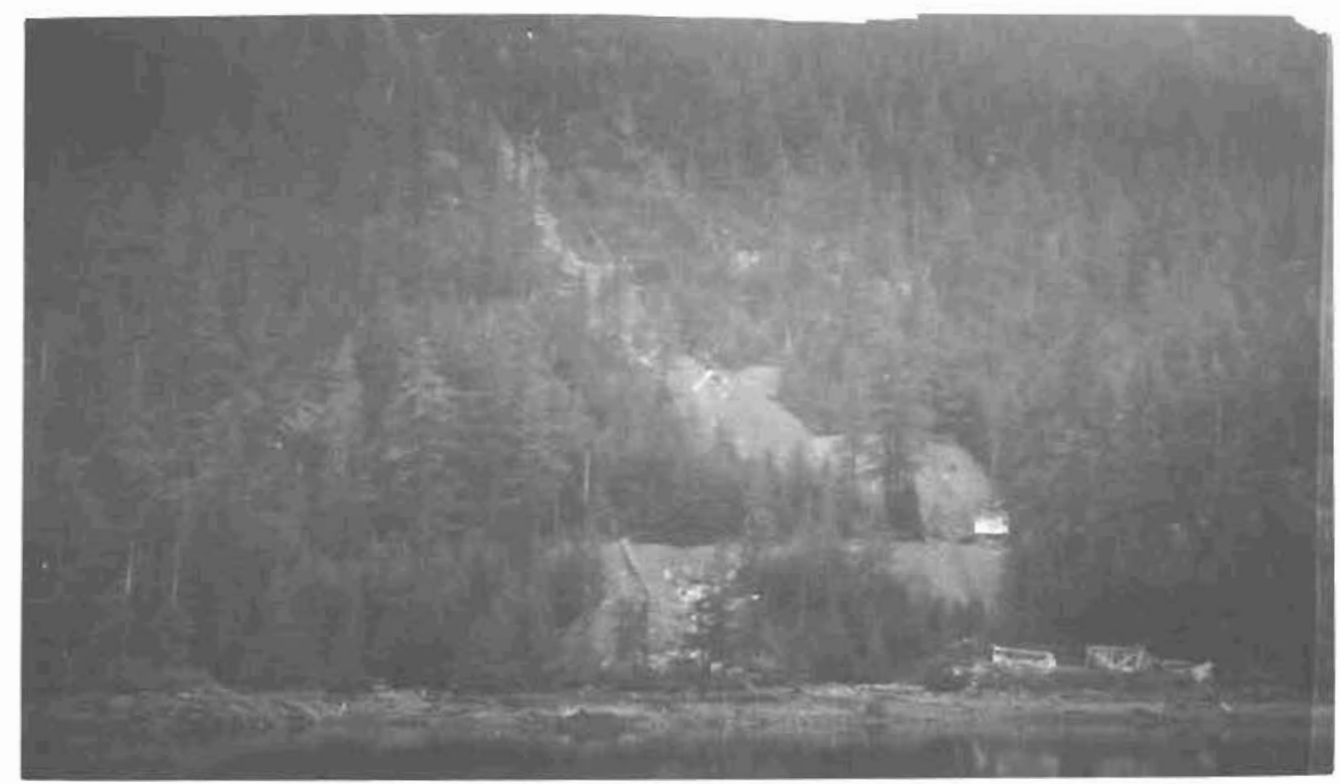

Figure 2. Another view of the property.

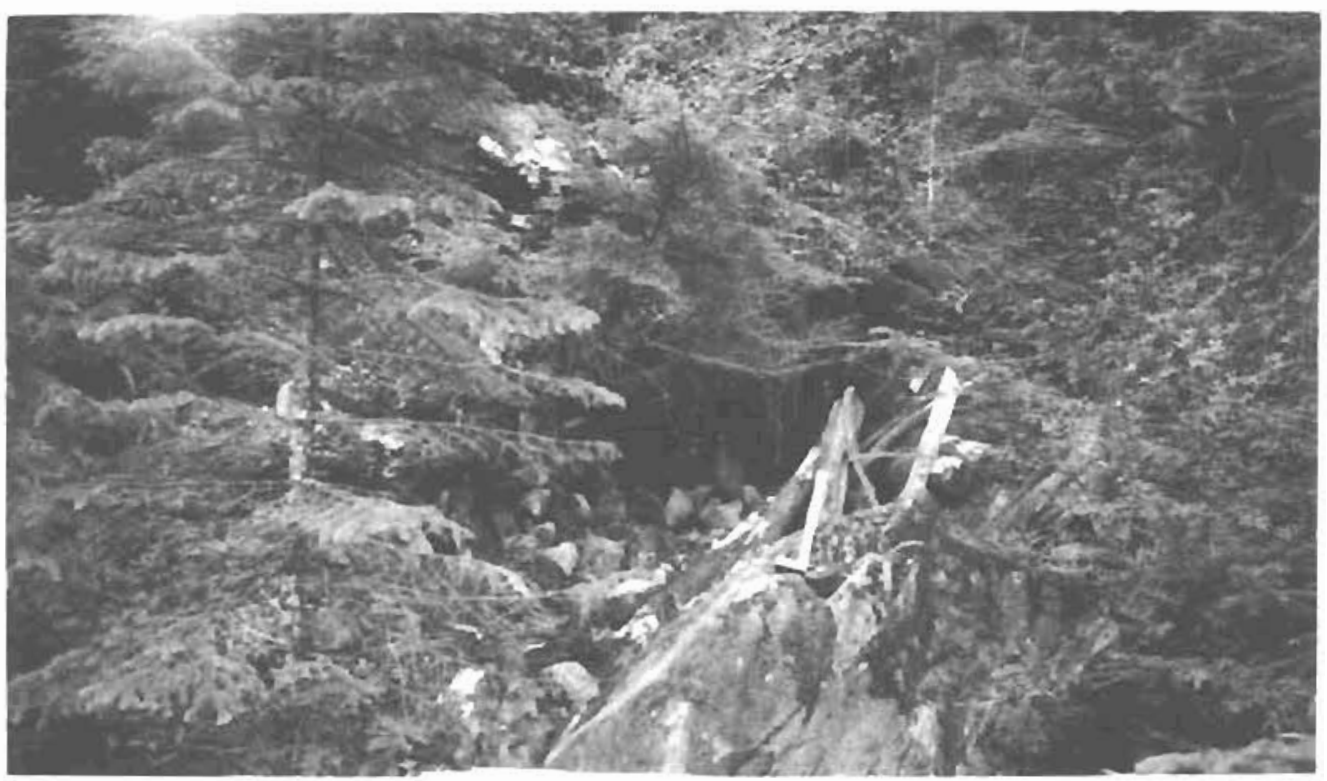

Figure 3. South portal of 5 Jevel (caved). 
TTMBER AND VEGETETION

Timber covers the slopes wherever it can gain a foothold, and is of sufficiently good grade for any use in conneotion with mining. Spruce and hemlock are the nost common. Good timber is grouring on the property. Undergrowth is heavy, due to the heavy precipitation, and it resembles that of SB Alaska.

A stream runs through the property just east of the workings that should take care of the fresh water requirements af a camp and mining operation.

\section{BUIDINGS AND EQUEPMENT}

A2l of the equipment and machinery originally on the property when active ls now gone. Even most of the rails have been taken from the workings. The buildings have all rotted to the point where they can hardly be used as firowood, much less shelter. Nothing salvable remains.

\section{GEOLOGY}

The country rocks of the vicinity are slate, greenstone, and graywacke of the Orca group.I/ The copper mineralization is mostly in a northwest-trending steeply-dipping shear zone that is more than 100 feet wide at the lower levels and narrows toward the upper levels. Extenstve faulting has occurred, and the larger

I. S. K. Capps and B. L. Johnson, The Ellamar District, ileska: U. S. Geol. Survey Bull., 605, 1915, p. 94. 
faults within the shear zone are evldently the local control of the highex-grade mineralization. The mineralization is apparently genersl, however, throughout the shear zone and further chalcopyrite wes noted in the primary greenstone outside of the sheer zone. The entire nearby vicinity shows indications of mineralization.

The overthrust Land lock Fault is just east of the property and thrusting toward it, thereby causing the shear zones in which the mineralization took place, partly by replacement and partly by fracture cementation.2/

Mineralization is in the form of sulfides: chalcopyrite, pyrite, pyrrhotite, sphalerite, and chalmersite. The chalmersite cannot be easily distinguished from chalcopyrite in hand speoimens, and gince it carries a lower percentage of copper than the chalcopyrite, one may get a slightly high impression of the ore values when estimating by eye.

The mining that was done was for the highongade portions of the mineralization only. These ore shoots are narrow bands of nearly solid sulfides that follow the above mentioned minor shears, striking $\mathrm{NW}$ and dipping $40^{\circ}$ to $60^{\circ} \mathrm{NE}$. The ore was hand-sorted to a ten percent or better product and then shipped, the remainder being left on the dump. There are two of the high-grade bodies, and as mentioned earlier, the lower-grade mineralization is general, and can be assumed to exist between the two high-grade bodies with 2] ToId. p. 95. 
fair certality. Only the ore shoots are indicated on Plate 3.

An adit high above the onss mapped was investigated whioh also shows strong mineralization. A short adit at water level on Keystone claim showing further good indications was checked, and geologic investigations around the point toward USLM No. 12 revealed two more adits with a common portal. Mineralization is good here also, with the high-grade portions carrying considerable pyrrhotite. These adits are not on the patented claims of the Dickey Group, and are indicated on the Bulletin 605 map as owned by a Peter Steimetz. The large number of prospects and mines in the Floinity show by the above map is further evidence of the wideaspread mineralization of the area.

\section{SAMPLING}

Channel samples were cut in the mine wherever it was safe to work; none were cut in any of the drifts under the stopes because of the condition of the timbering holding up the broken material. Sampling.was done in the stopes where possible wh thout setting up staging. Samples JW52-3 through JW52-24 were cut in the mino (locations shown on Plate 3), 25 through 27 were cut in the Stelnmetz adits, and $3652-28$ is a composite chip sample from the high drift. All samples we taken as nearly perpendicular to the dip as possible, and widths indicate the true thickness of structures sampled in each case. Sample 24 was taken of the highwgrede portion in the same chamel as 4 , and was not used in calculations. Results reported by A. E. Glover are showa on the following table. 


\begin{tabular}{|c|c|c|c|c|}
\hline Sample No. & Width. & of Copper & 2inc & $\mathrm{CO}-\mathrm{Ni}$ \\
\hline$\sqrt{15} 2-3$ & $36^{\prime \prime}$ & 0.87 & 0.2 & \\
\hline 4 & $58^{m}$ & 2.73 & 0.5 & \\
\hline 5 & $50^{n}$ & 2.22 & 0.4 & \\
\hline 6 & $32^{11}$ & 1.64 & 0.2 & \\
\hline 7 & $14^{\prime \prime}$ & $4 \cdot 38$ & 0.7 & \\
\hline 8 & $26^{\prime \prime}$ & 1.94 & 0.3 & \\
\hline 9 & $46 " 1$ & 4.10 & 0.4 & \\
\hline 10 & $40^{\prime \prime}$ & 1.27 & 0.2 & \\
\hline 11 & 5811 & Trace & 0.2 & \\
\hline 12 & $25^{\prime \prime}$ & 0.51 & 0.2 & \\
\hline 13 & $12^{\prime \prime}$ & 1.70 & 0.2 & \\
\hline 14 & $24^{n}$ & $\mathrm{~N} 11$ & 0.2 & \\
\hline 15 & $60^{\prime \prime}$ & 0.05 & 0.20 & \\
\hline 16 & $58 "$ & 0.149 & $0 . ?$ & \\
\hline 17 & $27^{\prime \prime}$ & 0.68 & 0.2 & \\
\hline 18 & $48 \pi$ & Trace & 0.25 & \\
\hline 19 & $8 n$ & 4.32 & 0.20 & \\
\hline 20 & 251 & 2.44 & 0.6 & \\
\hline 21 & $36 "$ & 2.98 & 0.2 & \\
\hline 22 & $46^{\prime \prime}$ & 0.98 & 0.2 & \\
\hline 23 & $24^{\prime \prime}$ & 4.70 & 0.5 & \\
\hline 24 & $12^{\prime \prime}$ & 11.76 & 2.3 & \\
\hline 25 & $22^{\prime \prime}$ & 2.92 & & Ni工 \\
\hline 26 & $17^{u}$ & 3.39 & & $\mathrm{NiI}$ \\
\hline 27 & $12^{\prime \prime}$ & 0.87 & & Nil \\
\hline 28 & Chip & 1.15 & & Nil \\
\hline
\end{tabular}


The samples were also assayed for gold and silver, but only in two high-grade samples mere gignificant results obtained, and then only in silver--samples 19 and 24 ran 2.00 and $1.20 \mathrm{oz}$ of silvex, respectivoly.

Wuch high-grade was found in the dump, bat it was bejond the writer's means at the time to indulge in the conparatively large operation of dump-sampling.

\section{RESERVES}

The owners of the Threeman property clalm 200,000 tons of 3\% ore to be blocked out. This statement may be true, bat could not be verified by the writer because of the inaccessibility of so many of the openings.

From the friter's vlewpoint, the sampling in this examination was too infrequent to allow an ore to be classed as proven. Probable ore extends fram the back of the 3 Level atope to the north drift of 2 Level at a calculated value and width of 2.39\% copper and 3.13 feet, respectively, making a reserve of probable ore of about 1920 tons of $2.39 \%$ ore.

The remainder of the ore must be inferred at present, but the possibilities for a large tonnage are good. The five samples taken in raises and stopes above the 2 Level average $2.60 \%$ at 2.31 feet, which infer an ore body of that grade and thickness to exist from there to the surface. Samples 21 and 23 alone average $3.67 \%$ at a width of 2.50 feet for the back of the 2 Level stope. 
The Threeman property's chief possibilities, however, Ife in the fact that the entire width of the shear zone, or at least the space between the earlier-mentioned two high-grade ore shoots, should be of about the average grade of all samples taken. It is true that many of the samples taken were "sweetened" somewhat with regard to the general grade in channeling across the high-grade band, but some of the sarnples were also taken where tine ground appeared comparatively berren, and several samples which ran $2 \%$ or better had little visual mineralization. Also, in many cases, the length of the channel eut was not the extent of the mineralization, but was the longest that could be cut within the confines of the stope or drift wille the mineralization continued. These facts added to the surface indications of general widespread mineralization, show the possibility that the entire shear zone is minable.

Calculattng conservatively between the probable locations of the two high-grade bodies from 5 Level to 1 Level, a block of about 100,000 tons of approximately $2 \%$ ore is possible. If one wished to extend calculations to the full width of the shear zone, the possible tonnage would be much larger.

As stated earlier, the dump contains much high grade, but was not sampled. Considering the facts that the workings are practically all within mineralized ground, and that the ore was handwsorted to about a $20 \%$ product before shipping, the writer believes that the durp must average at least $0.5 \%$ copper. No 1dea wos obteined as to the dump tonnage. 


\section{CONGLUSIONS}

The Threeman property has definitely good possibjilties of beconing a fairly large low-grade operation. The mine workings are in a well-mineralized shear zone up to a hundred feet wise and posslbly carrying as high as $2 \%$ copper for the full widtb. Only narrow high-grade shoots have been mined. The zone extends from about sea level to over 300 feet in elevation, narrowing toward the top, and dipping at about $45^{\circ}$. Figuring conservatively on the area between two oreshoots, a possible block of 100,000 tons of $2 \%$ ore 40 feet wide exists, and a probable block of 1920 tons of $2.39 \%$ ore 3.13 feet wide exists between the 3 Level stope and 2 Level. The durap is conservatively estimated to be at least $0.5 \%$ copper. This property should be extensively sampled underground and on the surface, and possibly some core drilling should be done, in order to more preclsely determine the value and extent of the mineralization before investing in preparations for an operation. All caved workings should be opened, if possible, and thoroughly investigated and sampled.

A wide body of $2 \%$ copper ore could be mined at a profit at present (1953) If the proper treatment plant were set up, ainc was separated, and concentrates could be shipped to a smelter relatively cheaply. If the other low-grade copper properties in the vicinity could be mined at the sarie time, and the ores sent to a nearby central treatment plant, milling costs could be reduced 
and greater production from the district would result. It naturally follows that a smelter in the Territory should also be considered.

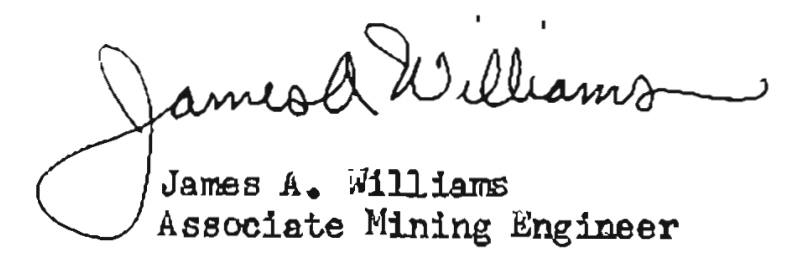




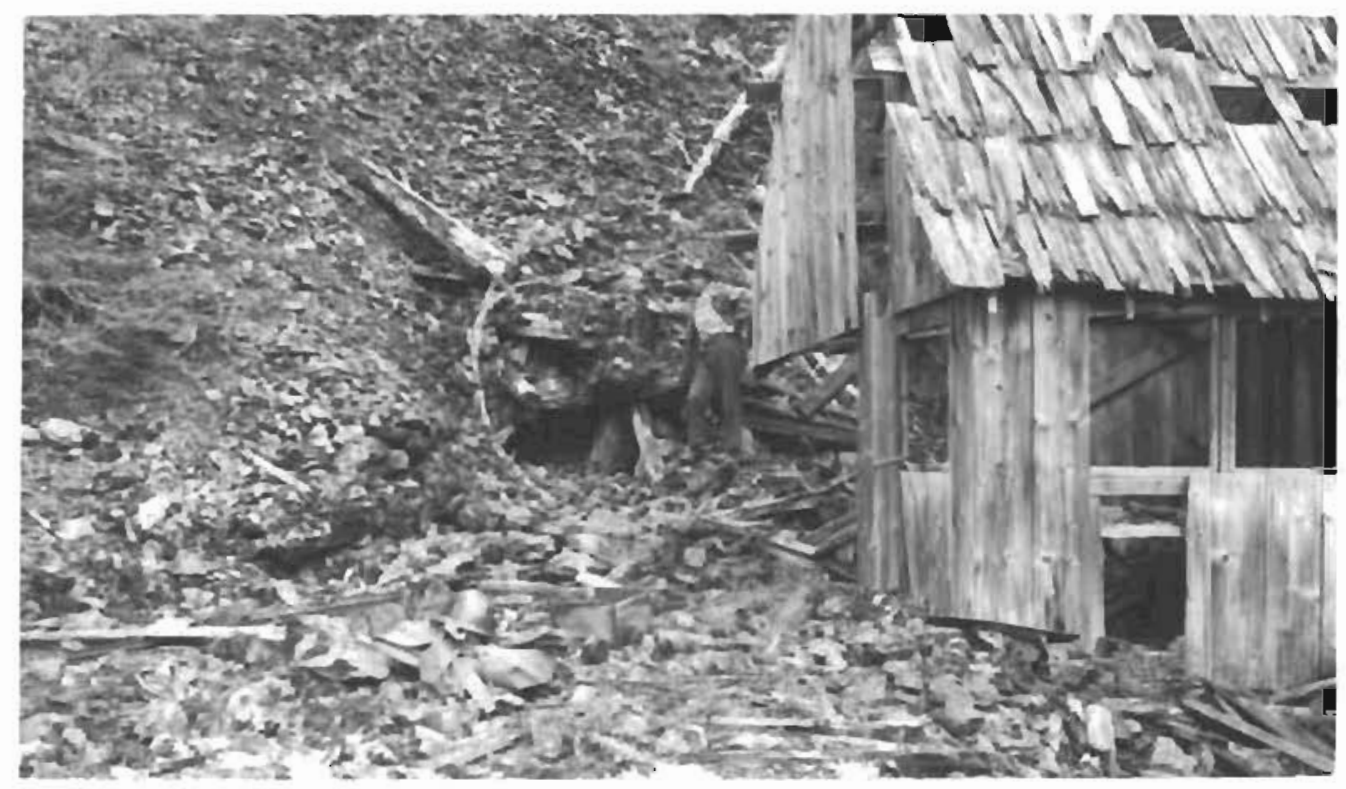

Figure 40 North portal of 5 Ievel (caved).

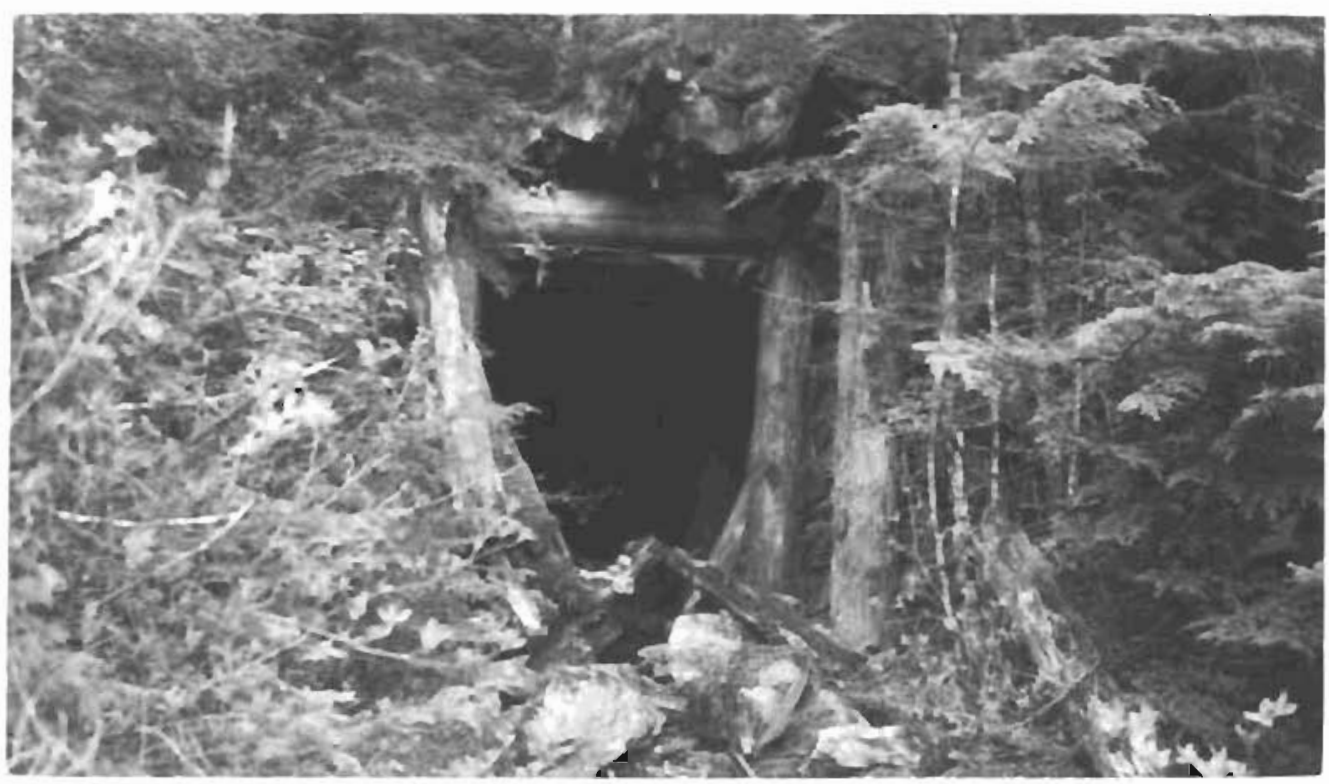

Figure 5. Portal of 3 Level. 


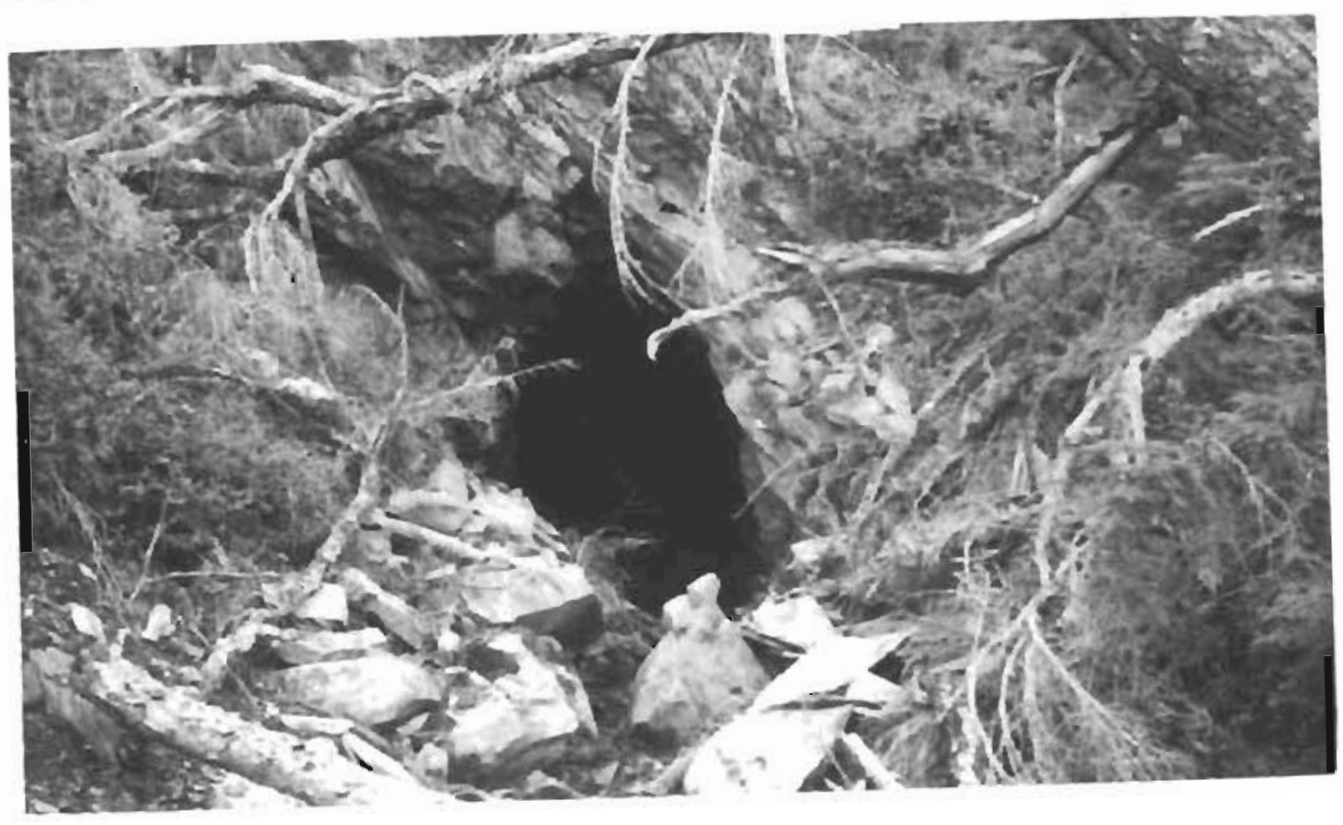

Figure 6. Portal of north 2 Level.

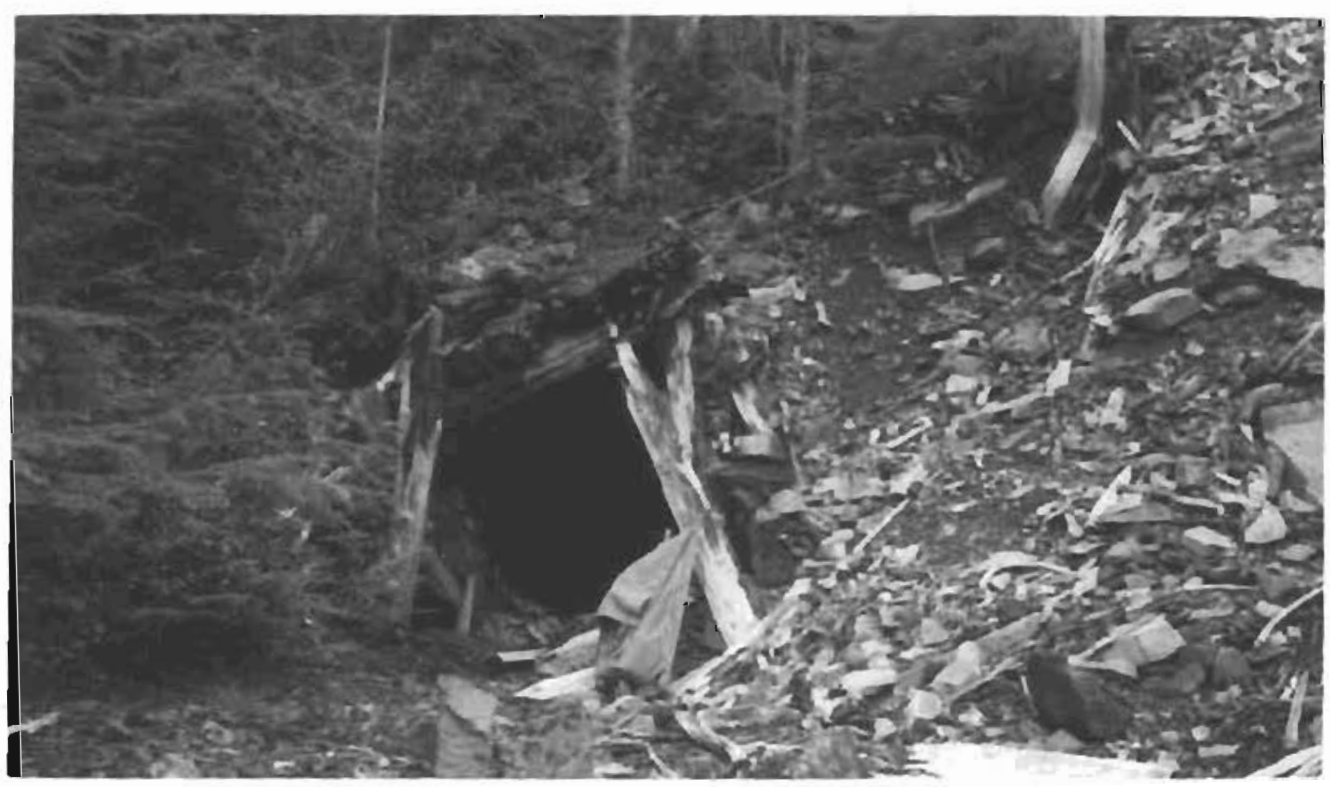

Figure ?. Portal of south 2 Ievel. 


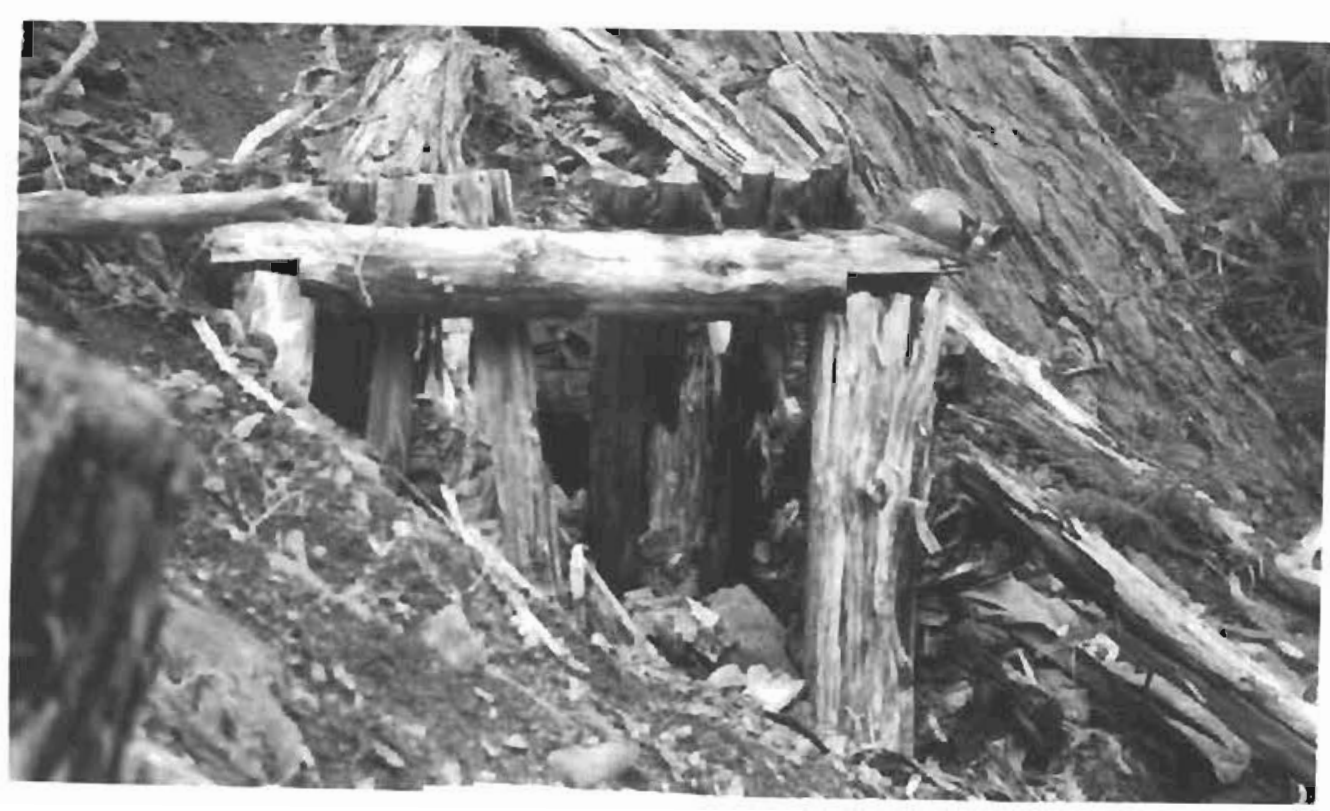

Figure 8. Portal of 1 Level.

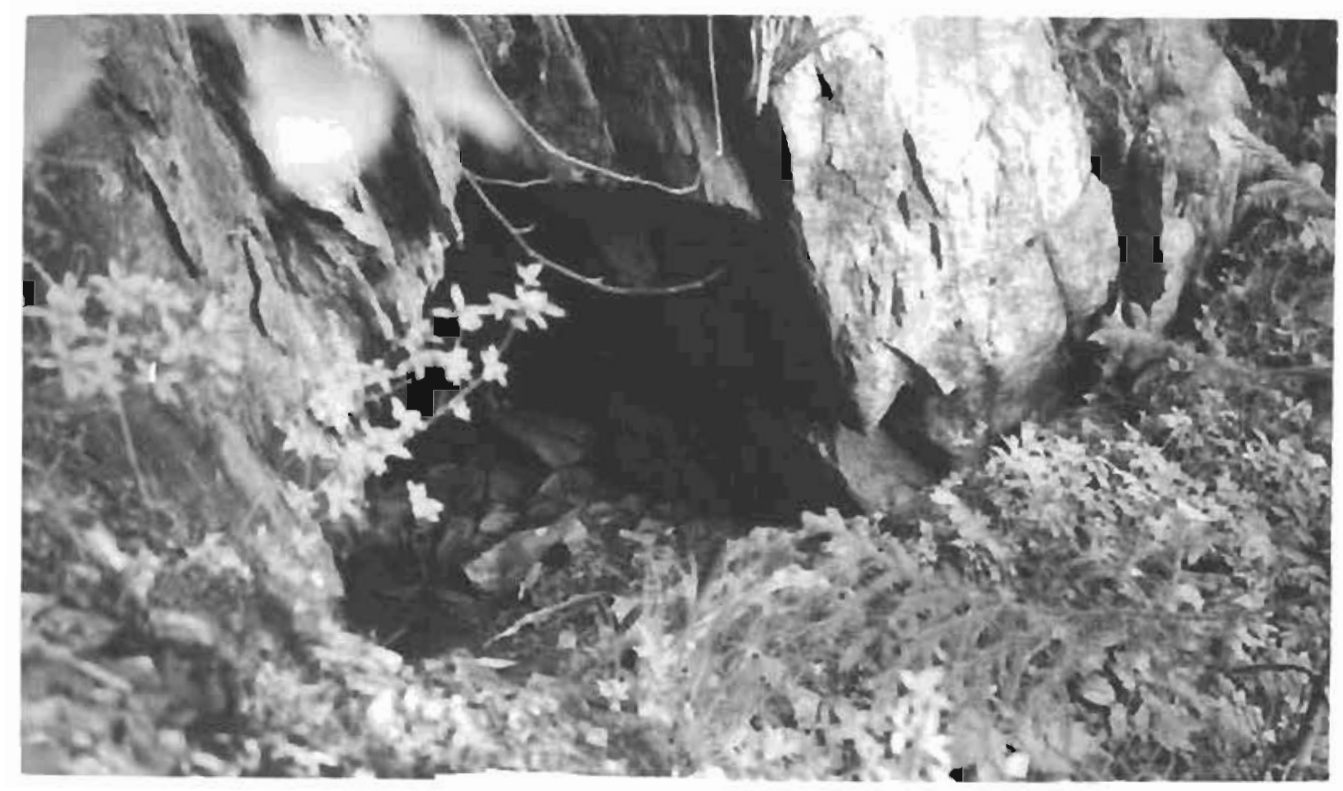

Figure 9. Portal of 0 Level, taken from above and to one side. 


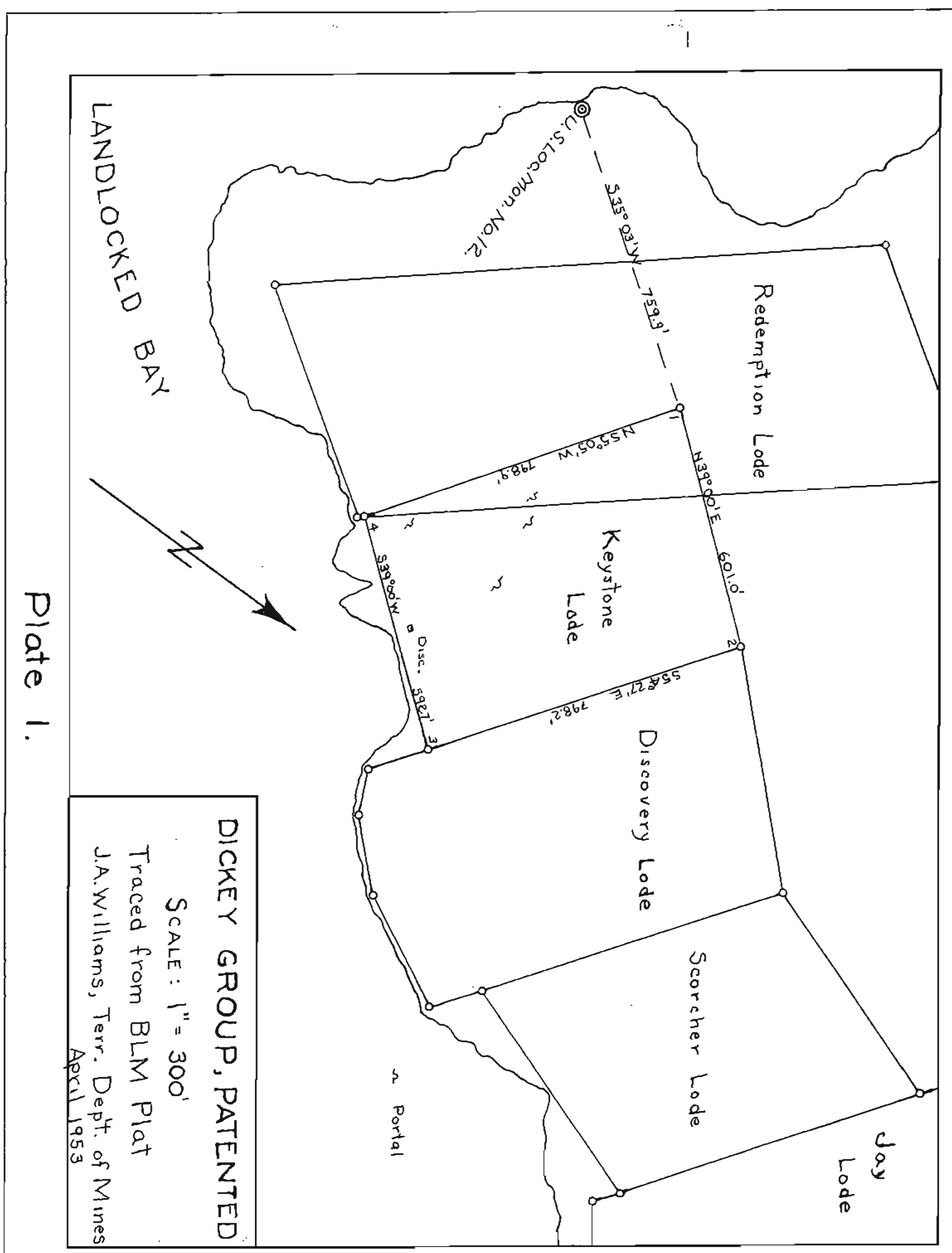




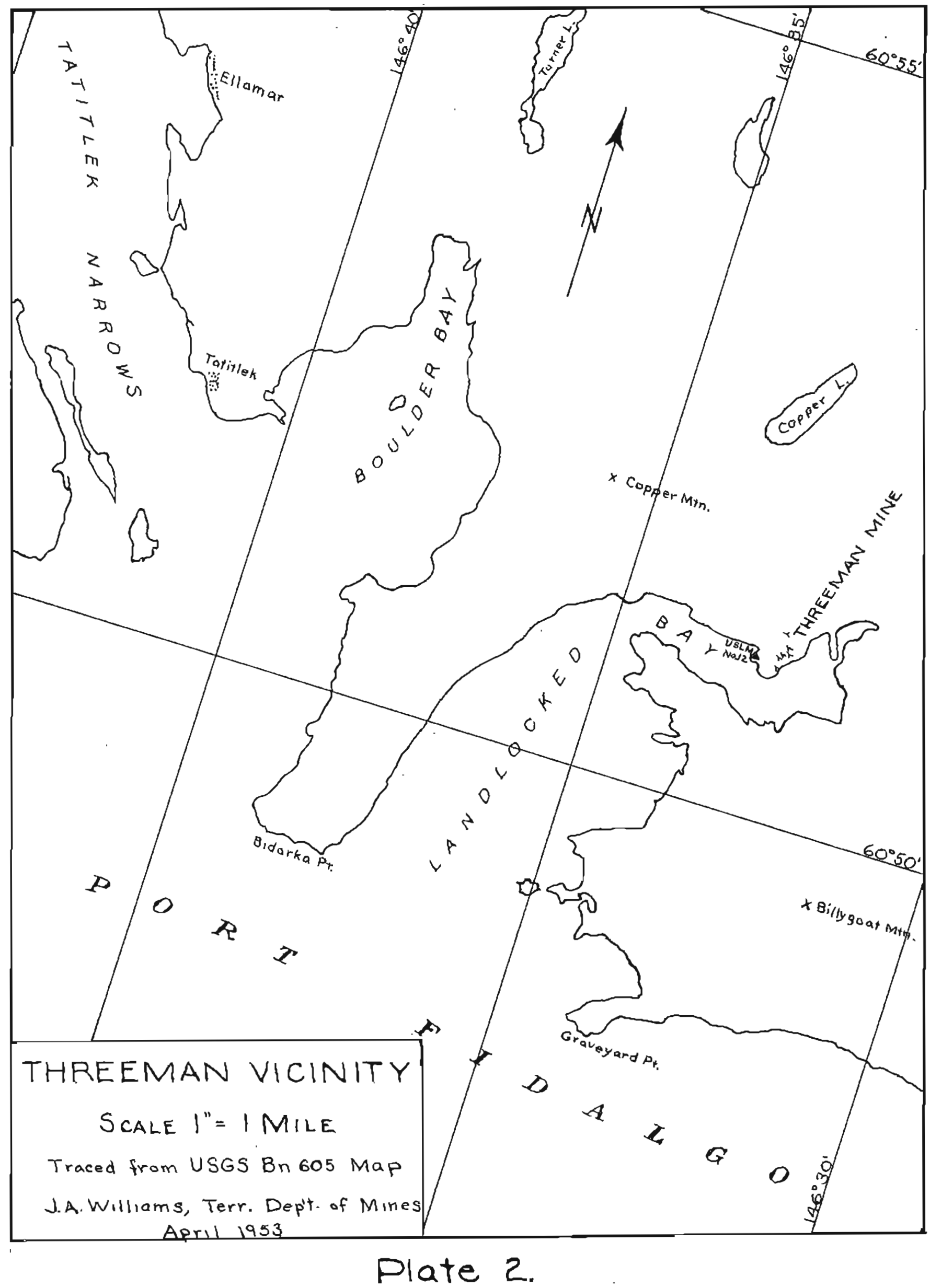

